\title{
IDENTIFIKASI NARKOTIKA JENIS TETRAHYDROCANNABINOL (THC) PADA URINE REMAJA
}

\author{
Rahmawati ${ }^{1)}$, Dewi Arisanti ${ }^{1)}$, Muh. Rifo Rianto ${ }^{1)}$ Mardatillah Ahmad ${ }^{1)}$ \\ ${ }^{1)}$ Teknologi Laboratorium Medis, Politeknik Kesehatan Muhammadiyah Makassar \\ Alamat Korespondensi: rahmawatiamma60@gmail.com
}

\section{Artikel info:}

Received: November 2021

Revised: Desember 2021

Accepted: Desember 2021

Publish: Desember 2021

\begin{abstract}
Abstrak
Narkotika meliputi cakupan drug yang berarti semua jenis zat yang apabila dipergunakan akan membawa efek dan pengaruh-pengaruh tertentu pada tubuh pemakai seperti menimbulkan gangguan pada sistem saraf, jantung, paru-paru, dan lain-lain. Faktor yang mempengaruhi terjadi penyalahgunaan narkotika pada remaja yaitu sebagian remaja yang orang tuanya sibuk pada urusan pekerjaan sehingga memberikan peluang anak merasa bebas (leluasa) untuk memasuki pergaulan atau perkumpulan yang diinginkan. Salah satu jenis narkotika yang sering disalahgunakan oleh para remaja adalah jenis obat tetrahydrocannabinol (THC). Tujuan dari penelitian ini adalah untuk mengidentifikasi narkotika jenis obat tetrahydrocannabinol (THC) pada remaja. Metode penelitian yang digunakan adalah purposive sampel dengan 15 sampel urine remaja dengan metode immunokromatografi. Hasil penelitian ini menunjukkan bahwa dari 15 sampel diperoleh 2 hasil positif ditandai dengan terbentuknya satu garis pada garis control $(C)$ dan 13 hasil negatif yang ditandai dengan terbentuknya dua garis merah pada garis control $(C)$ dan garis test $(T)$. Dengan demikian dapat disimpulkan bahwa 2 sampel urine remaja mengandung narkotika dan 13 sampel urine lainnya tidak mengandung narkotika jenis obat tetrahydrocannabinol (THC).
\end{abstract}

Kata Kunci: Narkotika, Tetrahydrocannabinol (THC), Metode Immunokromatografi

\begin{abstract}
Narcotics covers the scope of drugs which means all types of substances which when used will have certain effects and effects on the user's body such as causing disturbances to the nervous system, heart, lungs, etc. Factors that influence the occurrence of narcotics abuse in adolescents are some teenagers whose parents are busy in work affairs so as to provide opportunities for children to feel free (freedom) to enter the desired association or association. One type of narcotic that is often abused by teenagers is the type of drug tetrahydrocannabinol (THC). The purpose of this study was to identify the narcotic drug tetrahydrocannabinol (THC) in adolescents. The research method used was purposive sampling with 15 adolescent urine samples using the immunochromatographic method. The results of this study indicate that from 15 samples, 2 positive results were obtained, indicated by the formation of one line on the control line $(C)$ and 13 negative results which were indicated by the formation of two red lines on the control line $(C)$ and the test line (T). Thus, it can be concluded that 2 teenage urine samples contained narcotics and 13 other urinee samples did not contain the narcotic drug Tetrahydrocannabinol (THC).
\end{abstract}


Keywords: Narcotics, Tetrahydrocannabinol (THC), Immunochromatographic Method

\section{PENDAHULUAN}

Pada masa sekarang ini kata narkotika sudah tidak asing di telinga masyarakat dan generasi muda khususnya kalangan remaja. Adapun efek yang dapat ditimbulkan oleh narkotika seperti penurunan kesadaran, halusinasi, serta daya rangsang. Sebagian besar remaja menggunakan narkotika karena berbagai alasan mulai dari motif ingin tahu, cobacoba, adanya kesempatan dan saranaprasarana, ketidakstabilan emosi dan lemahnya mental. Selain itu beberapa faktor yang mendukung tindakan penyalahgunaan narkotika ini antara lain gangguan psikologis keluarga, kurangnya pendidikan agama, pergaulan dan budaya global (Waluyo, 2011).

Pengaruh narkotika dapat berupa pembiusan, hilangnya rasa sakit dan halusinasi atau timbulnya khayalankhayalan. Bahan-bahan narkotika yang lazim dipakai untuk pembiusan dalam dunia medis, misalnya pembiusan pada saat akan dilakukan tindakan operasi. Belakangan ini, istilah narkotika mengandung arti yang lebih luas dari sekedar obat pembius. Narkotika meliputi cakupan obat yang berarti semua jenis zat yang apabila dipergunakan akan membawa efek dan pengaruh-pengaruh tertentu pada tubuh pemakai (Wahid, 2016).

Adapun 3 jenis golongan narkotika yang sering disalahgunakan oleh para remaja yaitu: golongan I; jenis yang paling berbahaya dan memiliki daya adiktif yang sangat tinggi, memiliki manfaat untuk ilmu pengetahuan, contohnya seperti ganja, heroin, kokain, morfin dan opium. Golongan II; jenis yang memiliki daya adiktif kuat, tetapi memiliki manfaat sebagai pengobatan dan penelitian, contohnya seperti petidin, benzetidin, dan betametadol. Golongan III: jenis yang memiliki daya adiktif yang ringan, manfaatnya juga sebagai pengobatan dan penelitian, contohnya seperti kodein dan turunannya (Puspitarini, 2017).

Usia remaja merupakan masa pencarian jati diri. Remaja adalah masa peralihan dari anak-anak ke dewasa, bukan hanya dalam artian psikologisnya, melainkan juga fisiknya. Bahkan perubahan-perubahan fisik yang terjadi itulah yang merupakan gejala awal dalam pertumbuhan remaja. Sementara ini perubahan-perubahan psikologis muncul sebagai akibat dari perubahan fisik (Sarwono, 2012).

Oleh karena itu para remaja mengikuti arus pergaulan yang dilakukan oleh sekelompok temannya. Dilihat dari situasi dan keadaannya, daerah ini terkenal dengan kenakalan remaja salah satunya seperti mengkonsumsi obatobatan terlarang.

Beberapa senyawa yang dikelompokkan dalam cannabinoid seperti THC merupakan salah satu zat aktif yang memberikan efek psikis karena kandungan molekul psikoaktif. Dalam pemakaian dosis rendah senyawa tersebut dapat mengurangi rasa sakit, agresif, merangsang nafsu makan dan dapat membantu mengurangi rasa mual. Apabila narkotika digunakan secara terus menerus, pemakaian dalam dosis yang tinggi atau melebihi takaran yang telah ditentukan maka akan mengakibatkan ketergantungan. Ketergantungan dapat mengakibatkan efek negatif sehingga menimbulkan gangguan pada sistem saraf, gangguan pada jantung dan pembuluh darah, gangguan pada kulit, gangguan pada paru-paru, dan lain-lain (Camellia, 2011).

Penelitian yang telah dilakukan oleh Hariaji (2016) dengan judul Gambaran Penyalahgunaan Tetrahydrocannabinol (THC) dan Metamphetamin (MET) pada Usia Pra Kuliah di Kota Medan dan Sekitarnya, menunjukkan hasil bahwa sebagian besar pelajar yang menyalahgunakan narkotika 
berjenis kelamin laki-laki dan berada pada usia remaja dan sedang menempuh pendidikan.

Berdasarkan uraian di atas penulis tertarik untuk melakukan penelitian yang berjudul Identifikasi Narkotika Jenis Obat Tetrahydrocannabinol (THC) pada Remaja. Adapun tujuan dari penelitian ini adalah untuk mengidentifikasi narkotika jenis obat tetrahydrocannabinol (THC) pada remaja.

\section{METODE PENELITIAN}

\section{Alat dan Bahan Penelitian}

Alat yang digunakan pada penelitian ini adalah stopwatch, gunting, es batu, aluminium foil, isolasi/lakban, cooler box dan botol penampungan urine.

Bahan yang digunakan dalam penelitian ini adalah strip atau rapid test narkoba, dan urine.

\section{Prosedur Kerja \\ Pengambilan sampel}

Pengambilan sampel urine dilakukan secara purposive sampel atau pengambilan sampel didasarkan pada tujuan tertentu dengan memperhatikan ciri-ciri dan karakteristik seperti: berusia 18-21 tahun, lamanya mengkonsumsi THC 1-10 hari, badan kurus, mata memerah, terlihat lebih tua dari umurnya (Rahayu dan Solihat, 2018).

Disiapkan alat dan bahan yang akan digunakan, didesinfeksi alat dan bahan sebelum digunakan, ditampung urine yang akan diperiksa sebanyak kurang lebih $2 \mathrm{~mL}$ dengan menggunakan botol penampung urine yang steril.

\section{Pemeriksaan tetrahydrocannabinol} (THC)

Dibiarkan strip rapid test pada suhu kamar, dibuka penutup strip test kemudian dimasukkan strip rapid test narkoba secara vertikal ke dalam sampel urine yang sudah ditampung selama 10-15 detik, ketika strip test dicelupkan tidak boleh melewati batas garis yang paling bawah zona sampel (S). Diperhatikan tanda berwarna pada strip, didiamkan selama kurang lebih 5-10 menit. Setelah itu dilakukan pembacaan hasil (Muawanah dan Rasyid, 2020).

\section{Interpretasi Hasil}

Positif: jika terbentuk satu garis merah pada garis control $(\mathrm{C})$.

Negatif: jika terbentuk dua merah pada garis control (C) dan garis test (T).

Invalid: jika terbentuk satu garis berwarna merah pada garis di test (T).

\section{HASIL DAN PEMBAHASAN}

Berdasarkan hasil penelitian terhadap 15 sampel remaja yang dilakukan di Laboratorium Kimia dan Toksikologi Klinik Politeknik Kesehatan Muhammadiyah Makassar pada tanggal 7-23 April 2021, diperoleh hasil pemeriksaan pada sampel urine seperti pada tabel di bawah ini:

\section{Tabel 1. Identifikasi Narkotika Jenis Tetrahydrocannabinol (THC) pada Remaja}

\begin{tabular}{cc}
\hline $\begin{array}{c}\text { Kode } \\
\text { Sampel }\end{array}$ & Hasil \\
\hline 1 & Negatif (-) \\
2 & Negatif (-) \\
3 & Negatif (-) \\
4 & Negatif (-) \\
5 & Negatif (-) \\
6 & Negatif (-) \\
7 & Negatif (-) \\
8 & Negatif (-) \\
9 & Negatif (-) \\
10 & Negatif (-) \\
11 & Positif (+) \\
12 & Negatif (-) \\
13 & Negatif (-) \\
14 & Positif (+) \\
15 & Negatif (-) \\
\hline
\end{tabular}

Berdasarkan data di atas dari 15 sampel urine remaja maka diperoleh hasil penelitian 2 positif tetrahydrocannabinol (THC) dan 13 negatif tetrhydrocannabinol (THC). Penelitian ini dilakukan secara observasi laboratorik yang bertujuan untuk identifikasi narkotika jenis obat tetrahydrocannabinol 
(THC) pada remaja dengan jumLah sampel pemeriksaan sebanyak 15 sampel.

Metode rapid test merupakan metode yang sering digunakan untuk pemeriksaan narkotika jenis tetrahydrocannabinol (THC) pada urine remaja, dengan melihat reaksi yang terjadi pada strip yang digunakan, jika urine yang mengandung tetrahydrocannabinol (THC) maka terbentuk satu garis merah pada garis kontrol (C) sedangkan jika tidak mengandung tetrahydrocannabinol (THC) maka akan terbentuk dua garis merah pada garis $\mathrm{C}$ (Control) dan garis $\mathrm{T}$ (Test).

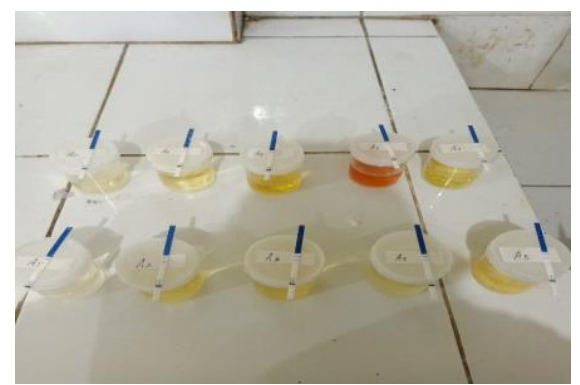

Gambar 1. Pemeriksaan Metode Rapid Test

Rapid Test mengandung konjugat drugs IgG anti narkoba, dimana substrat urine yang mengandung drugs akan bereaksi dengan konjugat. Tes ini urine yang diteteskan pada zona sampel sekitar 3-4 tetes kemudian tunggu beberapa saat (4-6 menit), amati garis yang berbentuk positif dengan ditandai garis satu pada kontrol (C), negatif ditandai dengan garis dua pada kontrol (C) dan test (T) (BNN, 2016).

Hasil penelitian tentang identifikasi narkotika jenis obat tetrahydrocannabinol (THC) pada urine remaja menggunakan metode immunokromatografi dengan keseluruhan sampel sebanyak 15 diperoleh 2 hasil positif ditandai dengan terbentuknya satu garis pada garis control (C), dan 13 hasil negatif yang ditandai dengan terbentuknya dua garis merah pada garis Control (C) dan pada garis test (T).

Hasil positif pada 2 sampel remaja memiliki ciri-ciri yang berusia 21 tahun dan 19 tahun yang termasuk remaja akhir, badan kurus, mata memerah, sering melamun dan remaja tersebut yang mengkonsumsi tetrahydrocannabinol (THC) tidak melebihi 1-10 hari pada saat pengambilan sampel sehingga hasil yang didapatkan positif.

Metode yang digunakan dalam pemeriksaan adalah imunokromatografi kompetitif, merendam strip secara vertikal dalam sampel urine, menunggu beberapa menit, memeriksa hasil jika ada garis pada kontrol, dan tesnya maka hasilnya negatif sedangkan garis pada kontrol menunjukkan positif. Jika garis tidak tercetak, menunjukkan hasil valid. Oleh karena itu, hasil yang diperoleh untuk sampel urine yang diuji menunjukkan hasil positif. Artinya, pasien adalah pengguna narkoba.

Sedangkan hasil negatif pada 13 sampel remaja dikarenakan jarang mengkonsumsi THC, sehingga tidak terdeteksi karena melebihi 1-3 hari. Pada pengguna yang jarang mengkonsumsi THC urinenya dapat terdeteksi dalam 1-3 hari (Camellia, 2011).

Berdasarkan penelitian sebelumnya yang telah dilakukan oleh Hariaji (2016), menunjukkan hasil bahwa sebagian besar pelajar yang menyalahgunakan narkotika berjenis kelamin laki-laki dan berada pada usia remaja dan sedang menempuh pendidikan.

Secara umum dapat dikatakan bahwa penyalahgunaan narkotika jenis tetrahydrocannabinol (THC) secara keseluruhan berada pada usia memiliki dampak negatif pada remaja berupa: perubahan dalam sikap, mudah tersinggung dan mudah marah, sering menguap, melamun, pemalas, tidak memperdulikan kesehatan dan penampilan diri, suka mencuri untuk membeli narkotika dan menyebabkan kegilaan, paranoid bahkan kematian (Hariaji, 2016).

\section{KESIMPULAN}

Berdasarkan hasil penelitian yang telah dilaksanakan di Laboratorium Kimia 
dan Toksikologi Klinik Politeknik Kesehatan Muhammadiyah Makassar dapat disimpulkan bahwa dari 15 sampel urine remaja yang diperiksa menunjukkan 2 hasil yang positif dan 13 lainnya negatif pada pemeriksaan tetrahydrocannabinol.

\section{DAFTAR PUSTAKA}

BNN. 2016. Balai Laboratorium Narkotika. Jakarta.

Camellia, V. 2011. Gangguan Sehubungan Cannabis. Modain: Departemen Psikiatri FK USU.

Hariaji. 2016. Gambaran Penyalahgunaan Tetrahydrocannabinol (THC) Dan Methamphetamine (MET) Pada Usia Pra Kuliah di Kota Medan Dan Sekiarnya Tahun 2016. EISSN: 2528-410X. 2(1).

Muawanah dan Rasyid, N.Q. 2020. Penuntun Praktikum Toksikologi 4.
Prodi D-III Teknologi Laboratorium Medis. Politeknik Kesehatan Muhammadiyah Makassar.

Puspitarini. 2017. Panduan Anti Narkoba Untuk Remaja. Esensi. Jakarta.

Rahayu, M dan Solihat, M. F. 2018. Toksikologi Klinik. Kemenkes RI. Jakarta.

Sarwono. 2012. Psikologi Remaja. YBPSP. Yogyakarta.

Wahid, A. 2016. Pelajar Indonesia Anti Narkoba. Erlangga. Jakarta.

Waluyo, B. 2011. Viktimologi Perlindungan Hukum Terhadap Korban Kejahatan, Sinar Grafika. Jakarta. 